\title{
The Effect of Grazing on the Temperature Regime of the Alas Soils of Central Yakutia
}

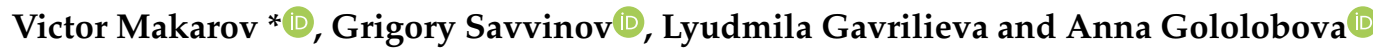

Scientific Research Institute of Applied Ecology of the North, M.K. Ammosov North-Eastern Federal University, 43 Lenin Prospekt, 677980 Yakutsk, Russia; savvinov_gn@mail.ru (G.S.); adoxa@mail.ru (L.G.); nuta0687@mail.ru (A.G.)

* Correspondence: mvs379@yandex.ru; Tel.: +7-4112-33-68-51

Received: 7 September 2020; Accepted: 22 September 2020; Published: 1 October 2020

\begin{abstract}
There are numerous studies on the effect of grazing on the physical and chemical parameters of soils. However, the impact of grazing on the temperature regime of the alas soils in Central Yakutia is still poorly understood. This paper presents the results of long-term observations of the state of the soil-and-plant cover of thermokarst basins-i.e., alases-located in the Lena-Amga interfluve and actively used as pastureland. Observations of the process of the self-restoration of grass cover and changes in the temperature regime of alas soils were carried out on different variants (with isolation from grazing and without isolation). A significant increase in the average height of the grass stand and its foliage projective cover was observed with a gradual reduction in the number of species when isolated from grazing. Changes in the structure of the alas vegetation cover influence the microclimate of the soil. As a result of livestock grazing, the mean annual soil temperature rises and the amount and depth of the penetration of active temperatures increase. The most severe changes in the temperature regime occur in years with an abnormally high cover of snow. The soil warming observed during grazing undoubtedly has a favorable effect on soil organisms. However, in conditions of climate warming, grazing, especially overgrazing, can disrupt the permafrost regime and thereby provoke or intensify thermokarst phenomena.
\end{abstract}

Keywords: soil temperature; climate change; alas soils; grazing

\section{Introduction}

A significant part of the hay and pasture lands of the Republic Sakha (Yakutia) is made up of alas meadows. In the Leno-Amga interfluve, they occupy up to $50 \%$ of the natural feeding ground area. The alas landscapes, widespread in Central Yakutia, led to the establishment and further development of the northernmost cattle-breeding culture there. The ancestors of the modern Yakuts in the 13th and 14th centuries brought horses and cattle with them when entering the Middle Lena basin. They organized hayfield and pasture farming and, for many centuries, made certain changes not only in economic life but also in the ecological and geographical appearance of the region, according to historians [1].

Dispersed population distribution over vast areas of the Lena-Amga interfluve was typical for this region until the 1920s. Therefore, the anthropogenic pressure on thermokarst landscapes was minimal. The expansion of livestock farms and the local concentration of livestock were the main reasons for the intensification of degradation processes [2-10], which began in the 1920-1940s and coincided with the Soviet period of collectivization in the last century.

Environmental mistakes in nature management were exacerbated by numerous unjustified organizational and economic decisions. For example, the enlargement of agricultural enterprises and the creation of large rural agglomerations in Central Yakutia happened without taking into account the environmental characteristics of taiga-alas ecosystems. According to Roman V. Desyatkin [6], 
the excessive enlargement of settlements was accompanied by a sharp reduction in forest areas, the main environment-forming factor in the conditions of an arid climate.

In the post-Soviet period, after the collapse of planned farms, private livestock became tied to pasture and hayfields near the communities. Thus, unsystematic grazing from early spring to late autumn for 145-165 days led to the complete degradation of pastures within a 3-5 km radius around settlements. Vegetation under such conditions is severely disturbed and represented by low-productivity species. The soil surface of pastures is often exposed; the foliage projective cover of the plants does not exceed $40-50 \%$ [5].

According to many researchers [9-17], the physical-hydrological and agrochemical properties of the soil are changed by overgrazing, along with the degradation of vegetation, including the compaction of the sod horizon to critical limits, a sharp decrease in the water permeability, the desiccation of the root-inhabited soil layer, an increase in alkalinity and salinity, and a decrease in humus and nutrients. The effect of grazing on the temperature regime of alas soils in Central Yakutia remains poorly studied to date. It is known that the thermophysical properties of the soil change during the compaction of the soil under the influence of domestic animals. Besides this, the penetration of direct sunlight into the upper layers of alas soils is enhanced with the active grazing of grass for livestock, especially in exposed sites. In this context, the aim of this study is to determine the effect of grazing on the temperature regime of alas soils.

\section{Materials and Methods}

A typical thermokarst alas of Nyagaatta ( $\left.\mathrm{N} 62^{\circ} 10^{\prime} 43,4^{\prime \prime} ; \mathrm{E} 132^{\circ} 00^{\prime} 19,3^{\prime \prime}\right)$ in the middle part of the Lena-Amga interfluve was selected for research. It is located near the village of Bere and is used as a pasture all year round (Figure 1).
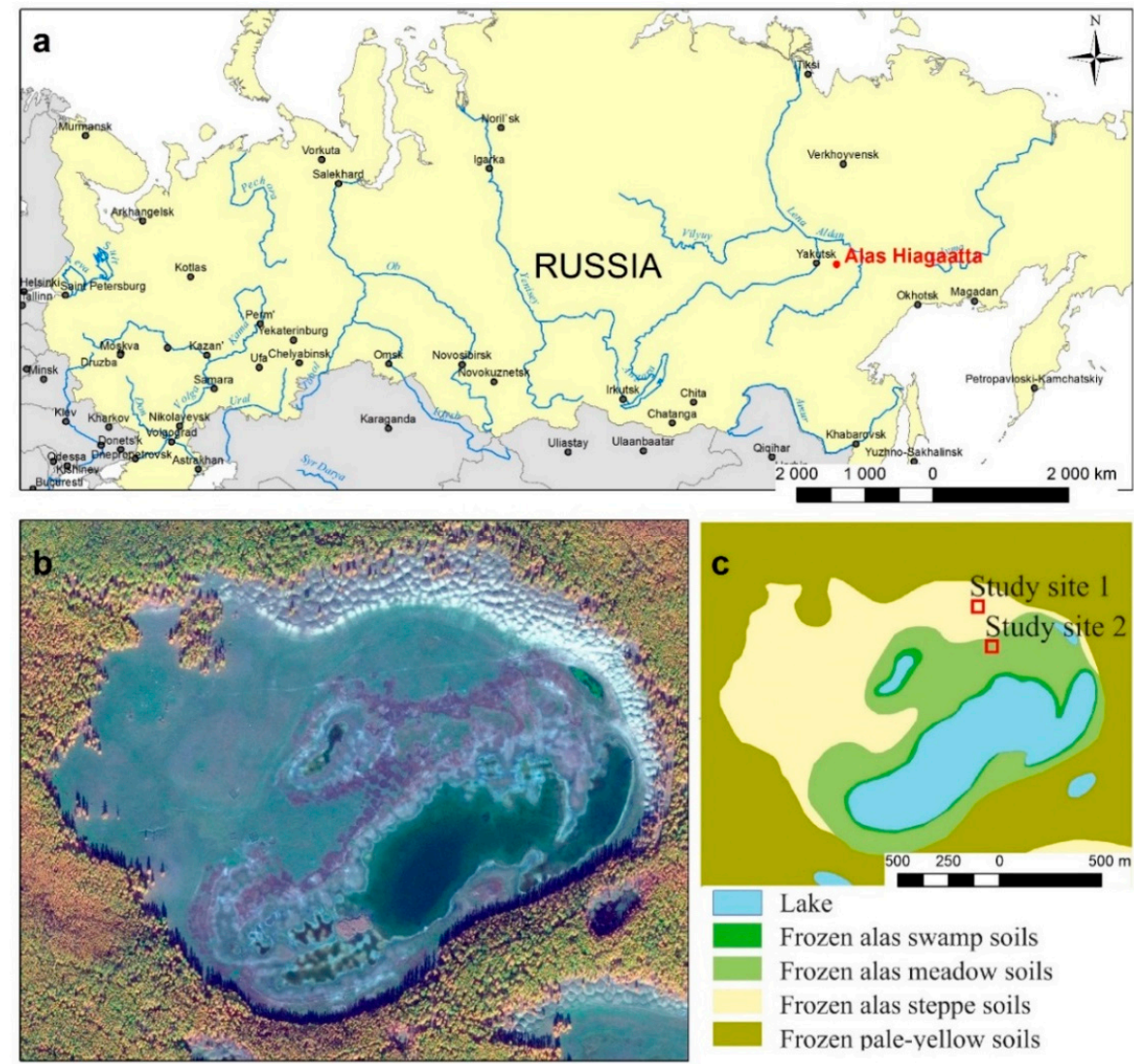

Figure 1. (a-c) Location of the study area. 
The weather conditions of the observed years are represented by the data of the weather station "Churapcha" (N 61 59'05"; E 132 $26^{\prime} 15^{\prime \prime}$ ), which is located $28 \mathrm{~km}$ southwest of the object of our research (Figure 2). The climatic characteristics of the research area based on the materials of the last 10 years of observations have the following indicators: the average annual air temperature is $-8.7^{\circ} \mathrm{C}$, the absolute maximum is $+37.4{ }^{\circ} \mathrm{C}$, and the absolute minimum is $-55.2^{\circ} \mathrm{C}$. On average, $281 \mathrm{~mm}$ of precipitation falls per year, and $2 / 3$ of the annual amount falls in April-October. The average maximum snow thickness is $0.37 \mathrm{~m}$. The territory is located in an area of continuous permafrost. The seasonal thawing of soil begins in early May and reaches from 1.5 to $3.0 \mathrm{~m}$ by the end of September.

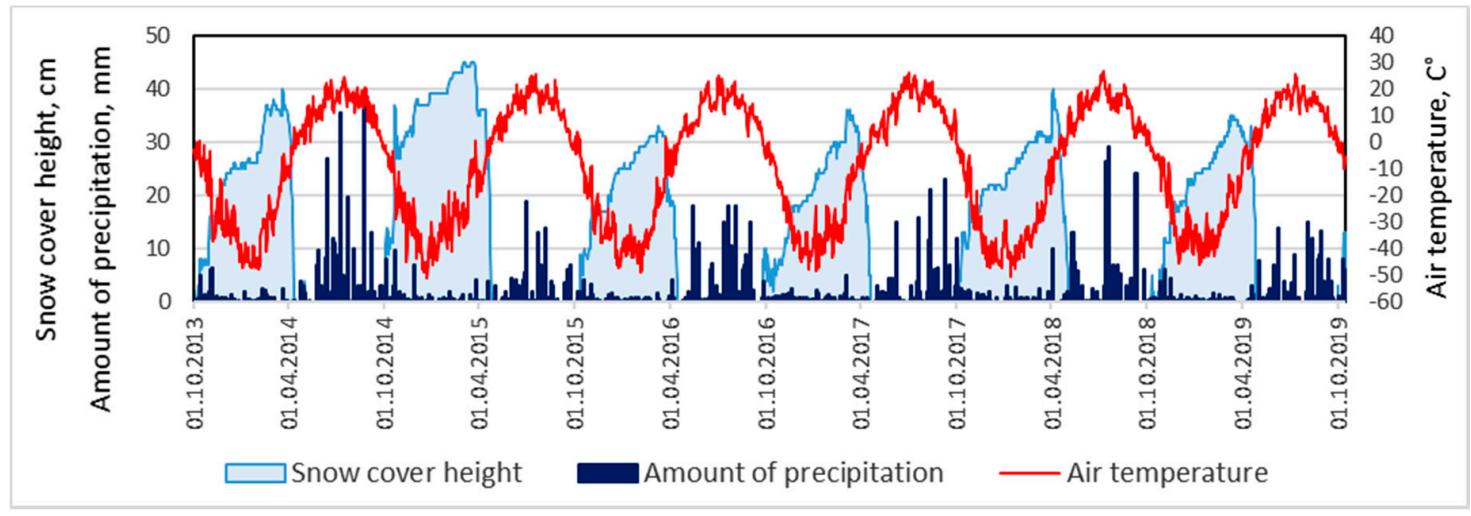

Figure 2. Annual variation in the air temperature, precipitation, and snow according to the weather station Churapcha.

In this project's framework, the specific fenced sites $7 \times 7 \mathrm{~m}$ in size were used in the northern part of the alas to isolate vegetation from the effects of cattle and horses (Figure 3). The Carex duriuscula (Elytrigia-type) site was isolated from grazing on the upper zone, dominated by Elytrigia repens (L.) Nevski and Carex duriuscula C.F. Mey. Alas steppe soils develop here, the granulometric composition of which is classified as loamy sand (according to the United States Department of Agriculture USDA classification). In World Reference Base WRB, these soils can be classified as Mollic Folic Cryosols (Figure 4a). The Puccinellia-type area was isolated from grazing in the middle belt, dominated by Puccinellia tenuiflora (Griseb.) Scribner et Merr, and the main accompanying species are Suaeda corniculata (C.A. Mey.) and Knorringia sibirica (Laxm.) Tzvel. Alas meadow soils develop here, the granulometric composition of which is classified as loamy sand (according to the USDA classification). In WRB, these soils can be classified as Salic Stagnic Solonetz (Figure 4b).

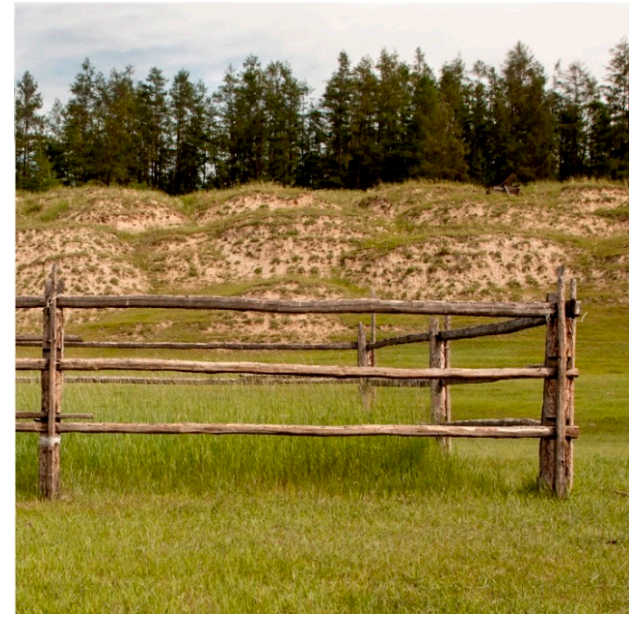

(a)

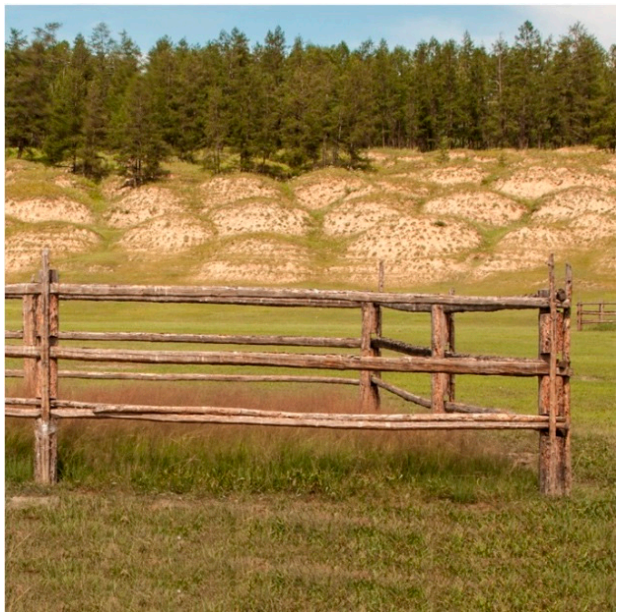

(b)

Figure 3. Photos of the experimental sites of the upper (a) and middle (b) zones of alas. 


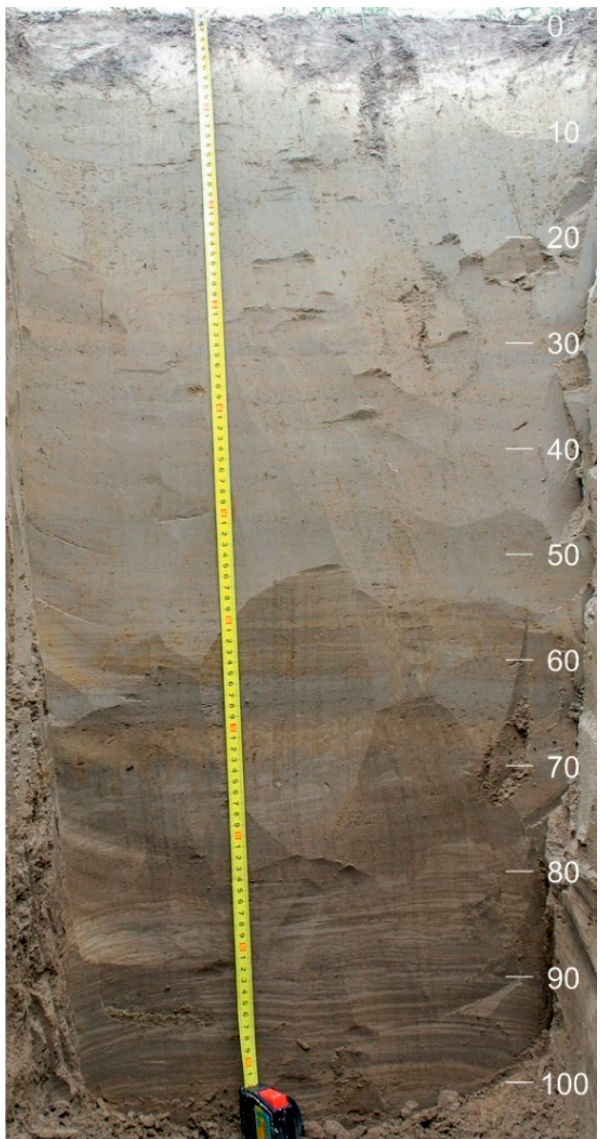

(a)

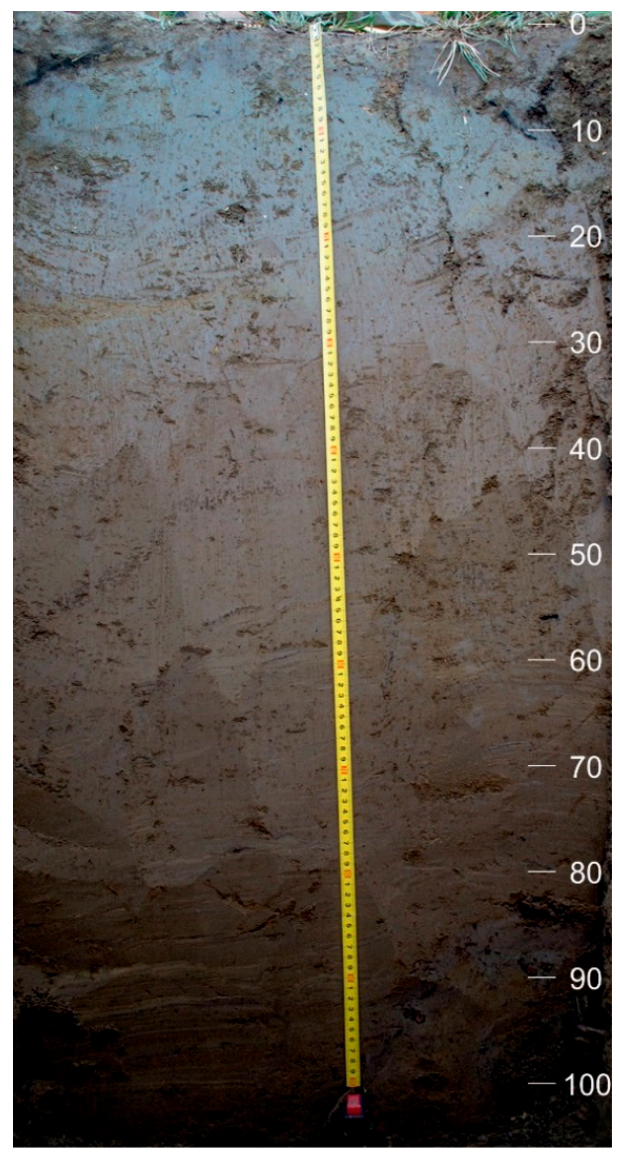

(b)

Figure 4. Soil profiles of the frozen alas steppe (a) and meadow (b) soils.

Observations of the process of the self-healing of grass cover and the change in the temperature regime on different variants (with isolation from grazing and without isolation) were carried out for 6 years, from the fall of 2013. Geobotanical surveys were carried out inside and outside the sites, according to generally accepted methods $[18,19]$, every year in mid-July. The foliage projective cover-i.e., the relative area occupied by the horizontal projection of the aboveground parts of plants on the soil surface, including the total projective cover in \% and the partial projective cover-was assessed visually according to the Brown-Blanquet scale for each species in points [20]. The height of the dominant species by biomass was measured in $\mathrm{m}$ (in 5 replicates) to determine the herbage's average height.

The iButton temperature loggers DS1921G-F5 (manufacturer-Dallas Semiconductor Corp.) were installed inside the fenced sites and $3 \mathrm{~m}$ from the fenced sites (on pastured grounds) at depths of 0 , $0.05,0.1,0.2,0.4,0.8$, and $1.2 \mathrm{~m}$. The minimum gradation of temperature registration is $0.5^{\circ} \mathrm{C}$, and the measurement error is $\pm 1.0^{\circ} \mathrm{C}$. This allowed us to study the distribution of soil temperature in depth and the temperature dynamics for 6 years in increments of $3 \mathrm{~h}$. Data processing was performed in Microsoft Excel and Golden Surfer 11.

The mean annual temperature of the soil at a depth of $0.2 \mathrm{~m}$, the sum of the active temperatures at a depth of $0.2 \mathrm{~m}$, and the depth of penetration of active temperatures were used to estimate the thermal soil resources. The sum of the active average daily temperatures above $10{ }^{\circ} \mathrm{C}$ at a depth of $0.2 \mathrm{~m}$ is the main indicator of the heat supply of permafrost soils in the cryolithozone of Russia. The biological parameter determining the active temperature in the soil at a depth of $0.2 \mathrm{~m}$ and equal to $10{ }^{\circ} \mathrm{C}$, above which the active vegetation of most plants begins, was adopted based on a detailed analysis of the USSR meteorological stations' data on air and soil temperatures [21]. 
The significance of differences between the four sites by temperature indicator was assessed using a statistical analysis ANOVA for repeated measurements (where the repeated measures are data for different years). The mean values of measurements do not differ from each other, as the null hypothesis for the analysis of variance of repeated observations asserts. Accordingly, an alternative hypothesis is that there is a difference between the mean values.

The significance of the differences in the thermal diffusivity of the steppe and meadow soils was assessed using the $t$-test.

\section{Results}

The foliage projective cover was always higher (from $80 \%$ to 100\%) in an isolated area of the upper zone than in areas with constant grazing (50-70\%) (Figure 5). A significant increase in the average height was observed in the first year of isolation (from 0.1 to $0.9 \mathrm{~m}$ ), as was a gradual decrease in the number of species. The abundance of Elytrigia repens significantly increased and it became the only dominant species. Poa pratensis L. appeared in the community from cereals (Poaceae). Synanthropic species dropped out in the first few years of isolation (Table 1). Indicators of the foliage projective cover and average height of grass remained at the same level in constant grazing. The composition of dominants and the main accompanying species did not change for five years.

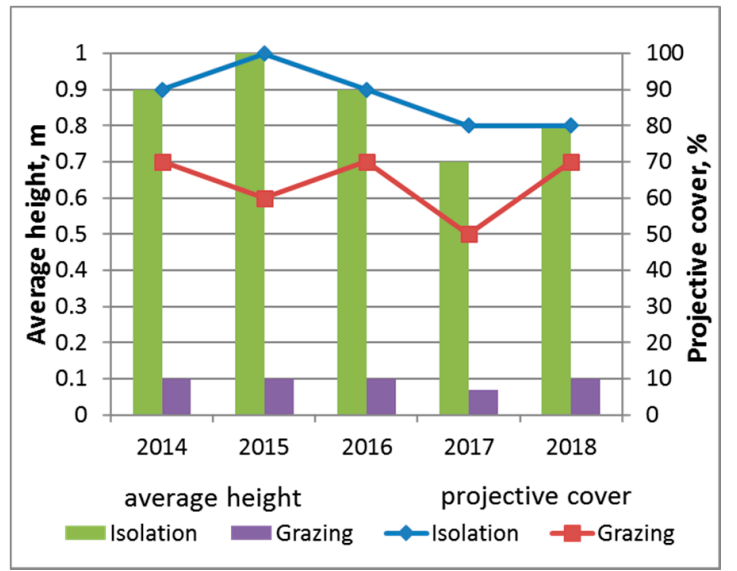

(a)

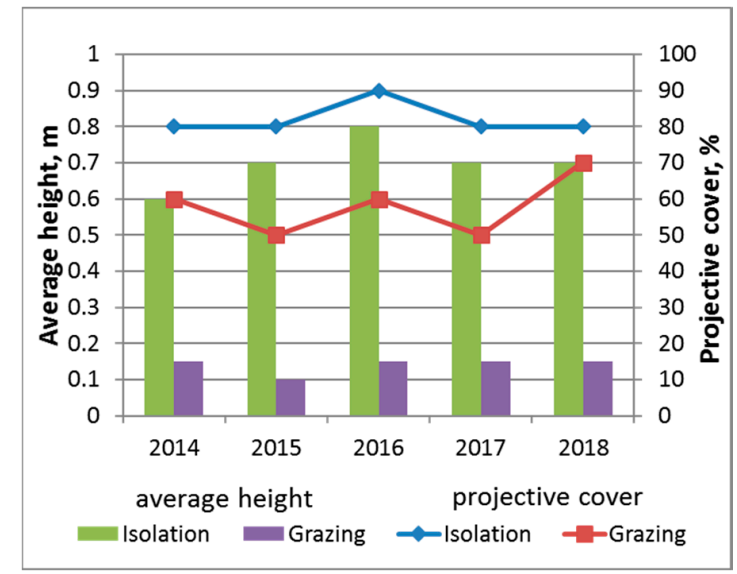

(b)

Figure 5. Changes in the structure of the community in the upper (a) and middle (b) zones.

Table 1. Dynamics of the species composition of the community of the upper zone.

\begin{tabular}{|c|c|c|c|c|c|c|}
\hline \multirow{2}{*}{ Indicator } & \multirow{2}{*}{ Before Isolation } & \multicolumn{5}{|c|}{ Years of Succession } \\
\hline & & 2014 & 2015 & 2016 & 2017 & 2018 \\
\hline \multicolumn{7}{|c|}{ Isolation } \\
\hline Elytrigia repens (L.) Nevski & 3 & 4 & 5 & 5 & 5 & 5 \\
\hline Carex duriuscula C.F. Mey. & 3 & 3 & 2 & 1 & 1 & 1 \\
\hline Poa pratensis L. & & + & 1 & 1 & + & + \\
\hline Taraxacum ceratophorum (Ledeb.) DC. & + & & + & + & & \\
\hline Veronica incana L. & 2 & 1 & & & & \\
\hline Descurainia sophia (L.) Webb. ex Plantl & + & & & & & \\
\hline Senecio jacobaea L. & 1 & & & & & \\
\hline Plantago media $\mathrm{L}$. & 1 & & & & & \\
\hline Lepidium densiflorum Schrad. & 1 & & & & & \\
\hline Arabis pendula $\mathrm{L}$. & + & & & & & \\
\hline Potentilla norvegica $\mathrm{L}$. & & + & & & & \\
\hline
\end{tabular}


Table 1. Cont.

\begin{tabular}{ccccccc}
\hline \multirow{2}{*}{ Indicator } & Before Isolation & \multicolumn{5}{c}{ Years of Succession } \\
\cline { 3 - 7 } & Grazing & $\mathbf{2 0 1 4}$ & $\mathbf{2 0 1 5}$ & $\mathbf{2 0 1 6}$ & $\mathbf{2 0 1 7}$ & $\mathbf{2 0 1 8}$ \\
\hline Elytrigia repens & 3 & 3 & 3 & 3 & 3 & 3 \\
Carex duriuscula & 3 & 3 & 2 & 2 & 2 & 2 \\
Taraxacum ceratophorum & + & + & 1 & 1 & & 1 \\
Veronica incana & 2 & 2 & 2 & 1 & 1 & + \\
Descurainia sophia & + & & 1 & + & & \\
Plantago media & 1 & 1 & + & 1 & + & + \\
Arabis pendula & + & + & + & & + & + \\
Senecio jacobaea & 1 & 1 & 1 & 1 & & \\
Lepidium densiflorum & 1 & + & 1 & + & 1 & + \\
\hline
\end{tabular}

Meaning of numbers: + , the species occurs singly; 1 , coverage up to $5 \% ; 2$, coverage from $5 \%$ to $25 \%$; 3 , coverage from $25 \%$ to $50 \%$; 4 , coverage from $50 \%$ to $75 \% ; 5$, more than $75 \%$ coverage.

The difference in the foliage projective cover between the isolated and uninsulated sites was in the range of $20-30 \%$ in the middle zone. A gradual increase in the foliage projective cover and the average height was observed during the first three years in isolation. Puccinellia tenuiflora remains dominant, increasing its abundance and displacing Suaeda corniculata from the community (Table 2). Small fluctuations in the total foliage projective cover of the grass were also observed in the grazing regime due to weather changes. The average height and species composition remained practically unchanged (Figure 5, Table 2).

Table 2. Dynamics of the species composition of the community of the middle zone.

\begin{tabular}{|c|c|c|c|c|c|c|}
\hline \multirow{2}{*}{ Indicator } & \multirow{2}{*}{ Before Isolation } & \multicolumn{5}{|c|}{ Years } \\
\hline & & 2014 & 2015 & 2016 & 2017 & 2018 \\
\hline \multicolumn{7}{|c|}{ Isolation } \\
\hline Puccinellia tenuiflora (Griseb.) Scriber et Merr & 3 & 4 & 5 & 5 & 5 & 5 \\
\hline Knorringia sibirica (Laxm.) Tzvel. & 2 & 2 & + & 1 & 1 & 1 \\
\hline Suaeda corniculata \{C.A.Mey (Bunge) & 2 & 1 & + & & & \\
\hline Elytrigia repens & 1 & + & & & & \\
\hline Lepidium densiflorum & 1 & & & & & \\
\hline Arabis pendula & 1 & & & & & \\
\hline Plantago media & 1 & & & & & \\
\hline Taraxacum ceratophorum & + & & & & & \\
\hline Potentilla anserina L. & + & & & & & \\
\hline \multicolumn{7}{|c|}{ Grazing } \\
\hline Puccinellia tenuiflora & 3 & 3 & 3 & 3 & 2 & 2 \\
\hline Elytrigia repens & 1 & + & + & 1 & + & 1 \\
\hline Taraxacum ceratophorum & + & + & + & + & + & + \\
\hline Knorringia sibirica & 2 & 2 & 1 & 1 & 3 & 3 \\
\hline Arabis pendula & 1 & & 1 & & 1 & + \\
\hline Suaeda corniculata & 2 & 2 & 2 & 2 & 2 & 3 \\
\hline Lepidium densiflorum & 1 & 1 & 1 & + & & + \\
\hline Plantago media & 1 & + & & & + & + \\
\hline Potentilla anserina & + & 1 & 1 & + & + & \\
\hline Descurainia sophia & & & + & + & & + \\
\hline
\end{tabular}

Meaning of numbers: + , the species occurs singly; 1 , coverage up to $5 \% ; 2$, coverage from $5 \%$ to $25 \%$; 3 , coverage from $25 \%$ to $50 \%$; 4 , coverage from $50 \%$ to $75 \% ; 5$, more than $75 \%$ coverage.

Noticeable changes in heat resources occurred during the isolation of the pasture. Thus, the mean annual temperature of the soil under the isolated site decreased by $0.7-1.7^{\circ} \mathrm{C}$ in the humus layer of 
the alas steppe soil (Figure 6). Minimum temperatures were observed in February and maximum temperatures in July. The mean annual temperature at the same depth decreased by $0.4-0.8^{\circ} \mathrm{C}$ during the isolation of the more moistened alas meadow soil. The relatively small decrease in the temperature of the alas meadow soil is probably due to its higher thermal capacity. In general, the mean annual temperature of the alas meadow soil was $1-2{ }^{\circ} \mathrm{C}$ higher than the temperature of the alas steppe soil, and during the instrumental period it never fell below $0{ }^{\circ} \mathrm{C}$.

The sum of active temperatures at a depth of $0.2 \mathrm{~m}$ decreased noticeably during the steppe soil isolation. The difference in the sum of active temperatures between grazing and isolation after the first year of research was $300{ }^{\circ} \mathrm{C}$; in subsequent years, the soil under the isolation became colder by $390-530^{\circ} \mathrm{C}$, and in some years this contrast reached up to $650{ }^{\circ} \mathrm{C}$ (Figure 7). The effect of isolation during the first two years was practically not observed in meadow soil. Only since the third year, the sum of active temperatures under isolation decreased by $480-560^{\circ} \mathrm{C}$. The meadow soil's inertness is related to its high level of moisture, especially after a snowy winter. The previous years were characterized by a large amount of precipitation; therefore, the meadow soil saturated with moisture after isolation cooled much more slowly than the steppe soil.

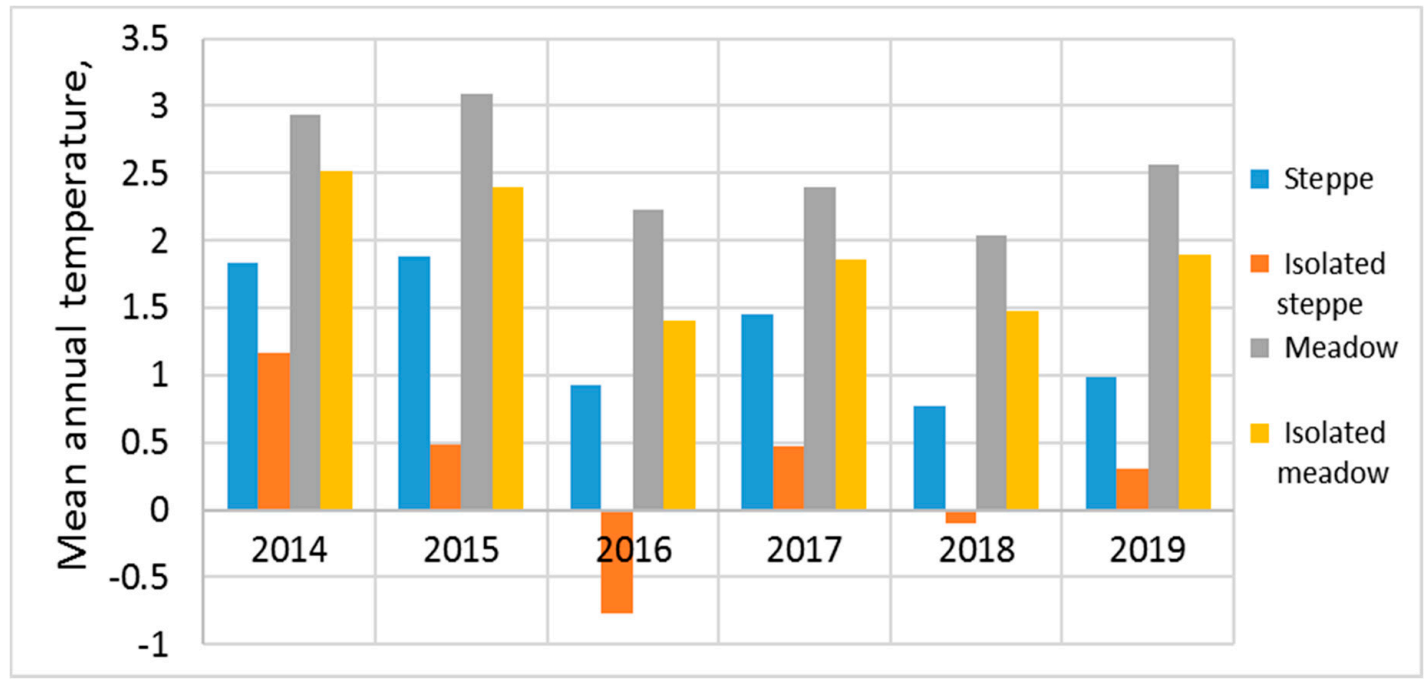

Figure 6. The change in the average annual temperature of alas soils at a depth of $0.2 \mathrm{~m}$. The F-ratio value is 97.30306. The $p$-value is $<0.00001$. The result is significant at $p<0.05$.

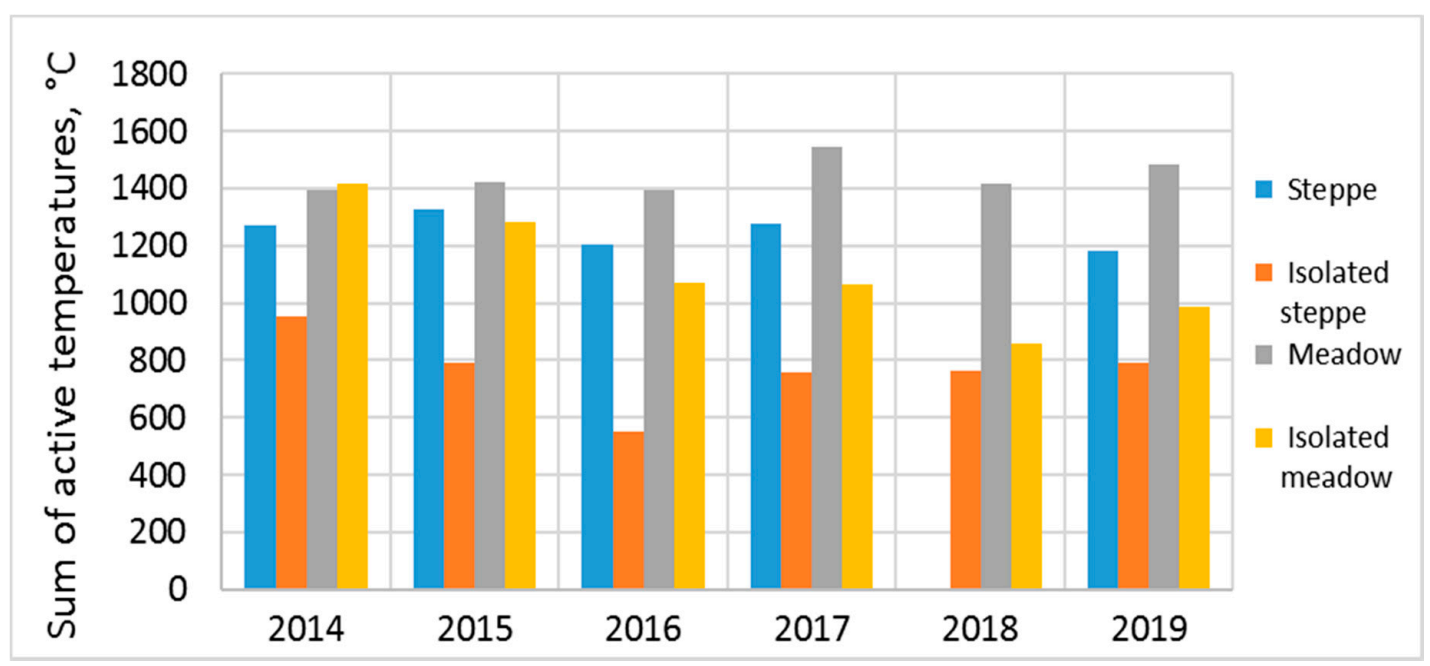

Figure 7. The change in the sum of active temperatures (above $10^{\circ} \mathrm{C}$ ) at a depth of $0.2 \mathrm{~m}$. The F-ratio value is 38.30557. The $p$-value is $<0.00001$. The result is significant at $p<0.05$. 
The penetration depth of active temperatures largely depends on the thermophysical properties of the soil. The profile distribution of the thermal diffusivity of steppe and meadow soil in summer is shown in Figure 8. The more moistened meadow soil significantly exceeds the steppe soil in this indicator, and the soil cools or heats faster and deeper, respectively.

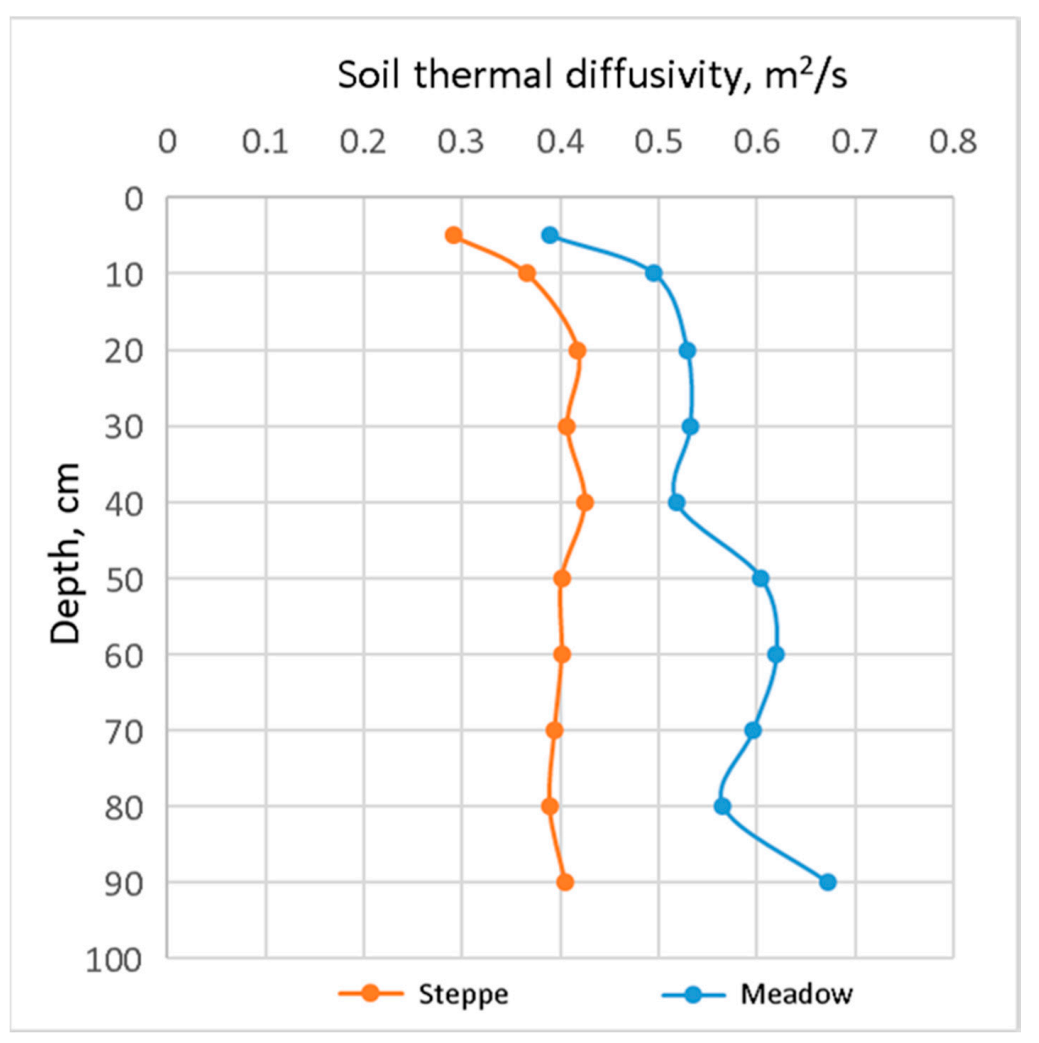

Figure 8. The change in the coefficient of thermal diffusivity of alas steppe and meadow soils. The $t$-test value is 8.68. The $p$-value is $<0.00001$. The result is significant at $p<0.05$.

The meadow soil was heated especially in the first years of research, where active temperatures (above $10^{\circ} \mathrm{C}$ ) were recorded at a depth of more than $1 \mathrm{~m}$ (Figures 9 and 10). It should be noted that such high temperatures are not typical for frozen soils, and this is obviously due to the weather anomalies of these years, when the thickness of the snow cover significantly exceeded the long-term norm and reached a thickness of up to $0.45 \mathrm{~m}$.

It is known that the coefficient of thermal conductivity of snow is much less than the coefficient of the thermal conductivity of soil. The amount of heat that is transferred through the snow layer depends on the thickness of this layer as for any substance. The thicker the snow cover, the slower the soil cools down in winter and the faster it warms up the next summer.

The maximum thickness of the snow cover varied from 0.25 to $0.61 \mathrm{~m}$ in the last 15 years according to the Churapcha weather station. Such a significant spread allowed us to classify hydrological years by the amount of hard precipitation. Thus, it is possible to attribute little snow to such years when less than $30 \mathrm{~cm}$ of solid precipitation fell, normal to years during which $30-40 \mathrm{~cm}$ fell, and multi-snow to years during which more than $40 \mathrm{~cm}$ fell.

The difference in the cooling of alas soils depending on the year's snow depth is visible in Figure 10. The penetration depth of negative temperatures was much less in the snowy winter of 2014-2015 than the penetration of negative temperatures in the dry winter of 2018-2019. For example, the temperature $-5{ }^{\circ} \mathrm{C}$ reached a depth of $0.35 \mathrm{~m}$ in steppe soil and only up to $0.05 \mathrm{~m}$ in meadow soil during a snowy winter. The temperature of $-5^{\circ} \mathrm{C}$ reached a depth of $0.95 \mathrm{~m}$ in steppe soil and up to $0.6 \mathrm{~m}$ in meadow soil during a dry winter. 


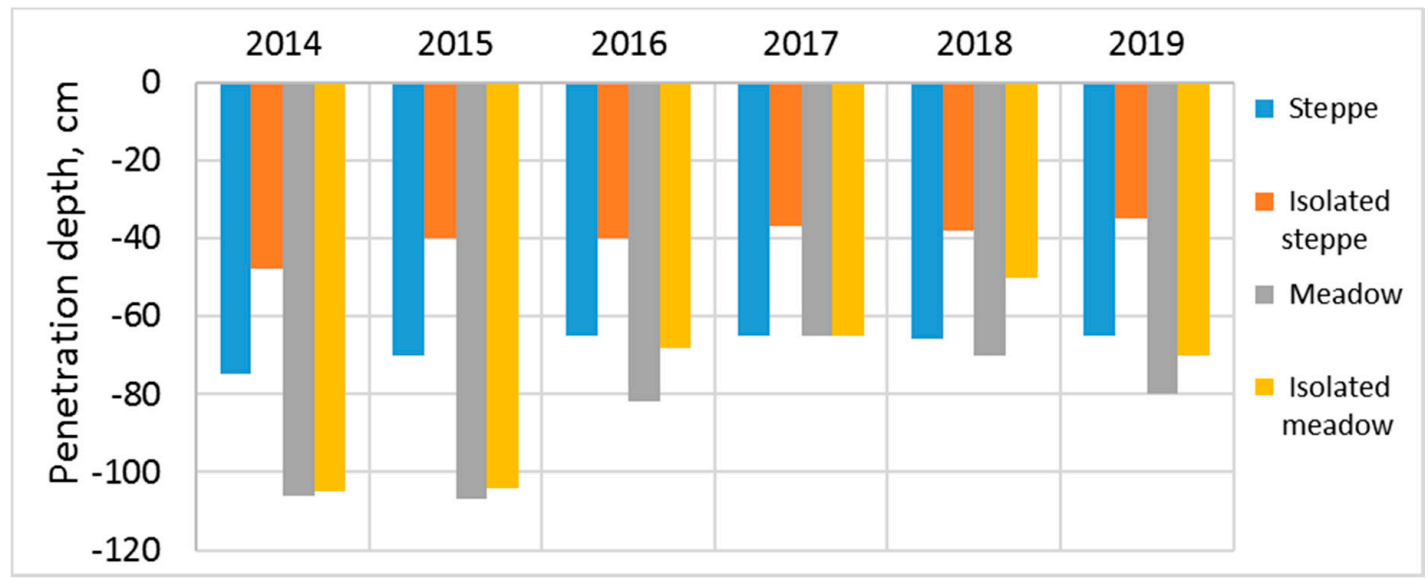

Figure 9. The change in the penetration depth of active temperatures (above $10^{\circ} \mathrm{C}$ ). The F-ratio value is 22.45181. The $p$-value is $<0.00001$. The result is significant at $p<0.05$.

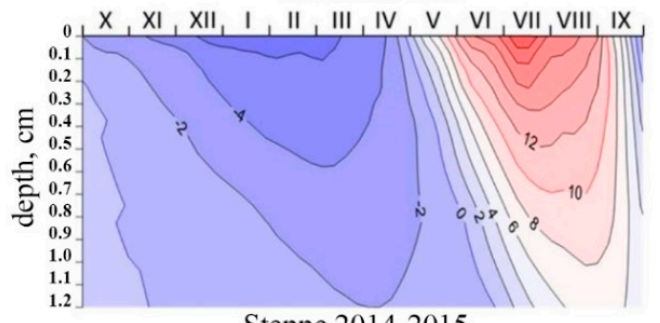

Steppe 2014-2015

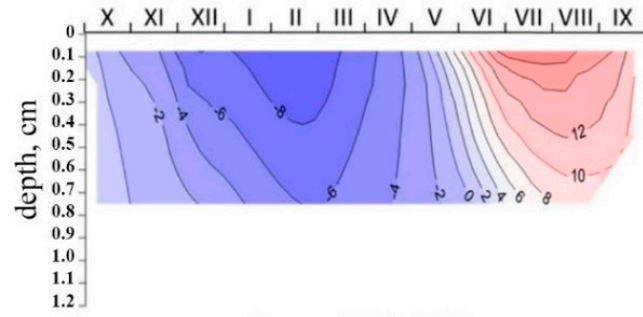

Steppe 2018-2019

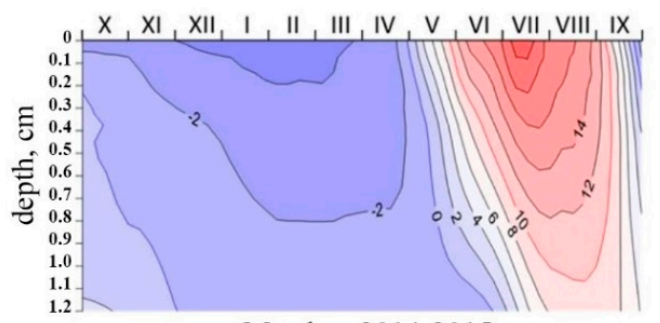

Meadow 2014-2015

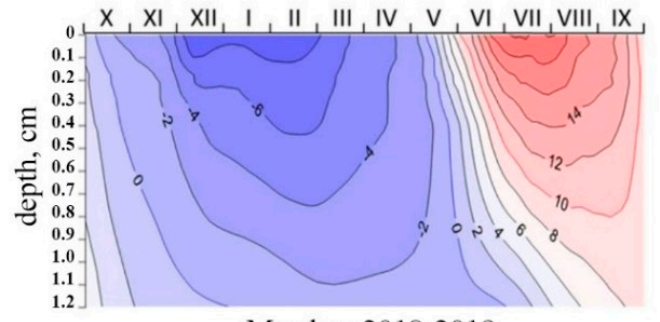

Meadow 2018-2019

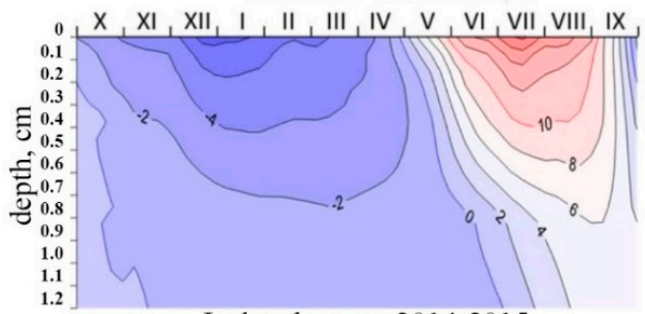

Isolated steppe 2014-2015

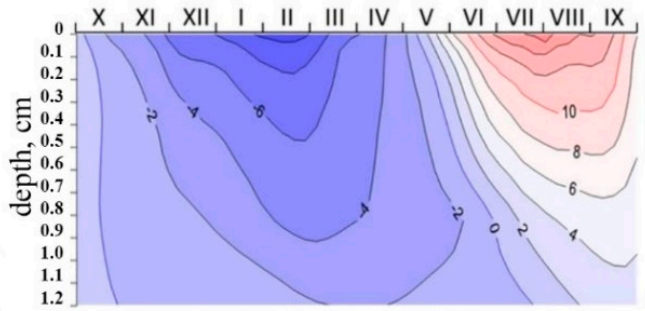

Isolated steppe 2018-2019

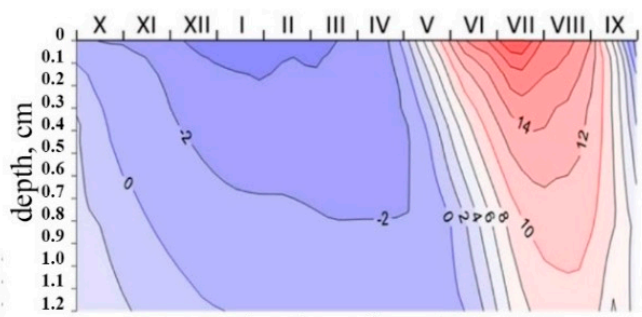

Isolated meadow 2014-2015

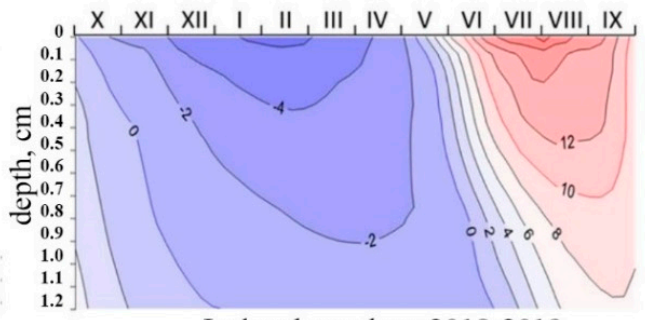

Isolated meadow 2018-2019

Figure 10. Thermoisoplets of alas soils. 
The penetration depth of negative temperatures decreased after isolation in the steppe soil, but the cooling of the upper humus layers increased. Apparently, the soil under the vegetation of isolated sites goes into "winter hibernation" in a dryer state and, accordingly, has less thermal conductivity than the soil under grazing. Therefore, cooling mainly occurs from the upper layers of the soil.

The process of soil cooling slows down uniformly throughout the soil profile when the meadow is isolated. This is especially noticeable in dry snow years. Such snow is less compacted under the grass vegetation, and, accordingly, it is characterized by a large thermal resistance.

It is well-known that the more the soil cools in winter, the slower the defrosting during the warm season. Therefore, the penetration depth of positive temperatures also depends on the thickness of the snow cover. The highest penetration depths of positive temperatures were recorded after the snowy winter of 2014-2015. Thus, the penetration depth of temperatures above $10^{\circ} \mathrm{C}$ in steppe soil reached $0.7 \mathrm{~m}$, and in meadow soil it reached up to $1.05 \mathrm{~m}$. Highly frozen soils were heated more slowly after a dry winter, and as a result the penetration depth of active temperatures decreased by $0.05 \mathrm{~m}$ in steppe soil and $0.25 \mathrm{~m}$ in a meadow soil.

The penetration depth of positive temperatures in isolated sites is always less than in pastures. A particularly strong effect of isolation is manifested in steppe soils. Moreover, the difference in the penetration of active temperatures between grazing and isolation does not practically depend on the year's snow depth, and it was $0.25-0.3 \mathrm{~m}$. As for meadow soil, a decrease in the penetration depth of active temperatures after isolation was not always observed, especially in the early years of isolation, when the maximum snow cover was observed. The consequences of isolation were only found after four years, where the contrast between grazing and isolation was $0.2 \mathrm{~m}$.

All the studied soils belong to the cold permafrost type according to the Russian classification system of temperature regimes. The main focus is on the temperature indicators of the root layer in this classification system. In soil taxonomy, the soil temperature reference site is either $50 \mathrm{~cm}$ below the soil surface or at the top of the root boundary layer-whichever is less. According to this system, the temperature regime of steppe soils belongs to the subgelic class, and the temperature regime of meadow soils belongs to the frigid class (Figure 11). In snowy years (2015), the steppe soil under the pasture becomes warmer and passes into the frigid class.

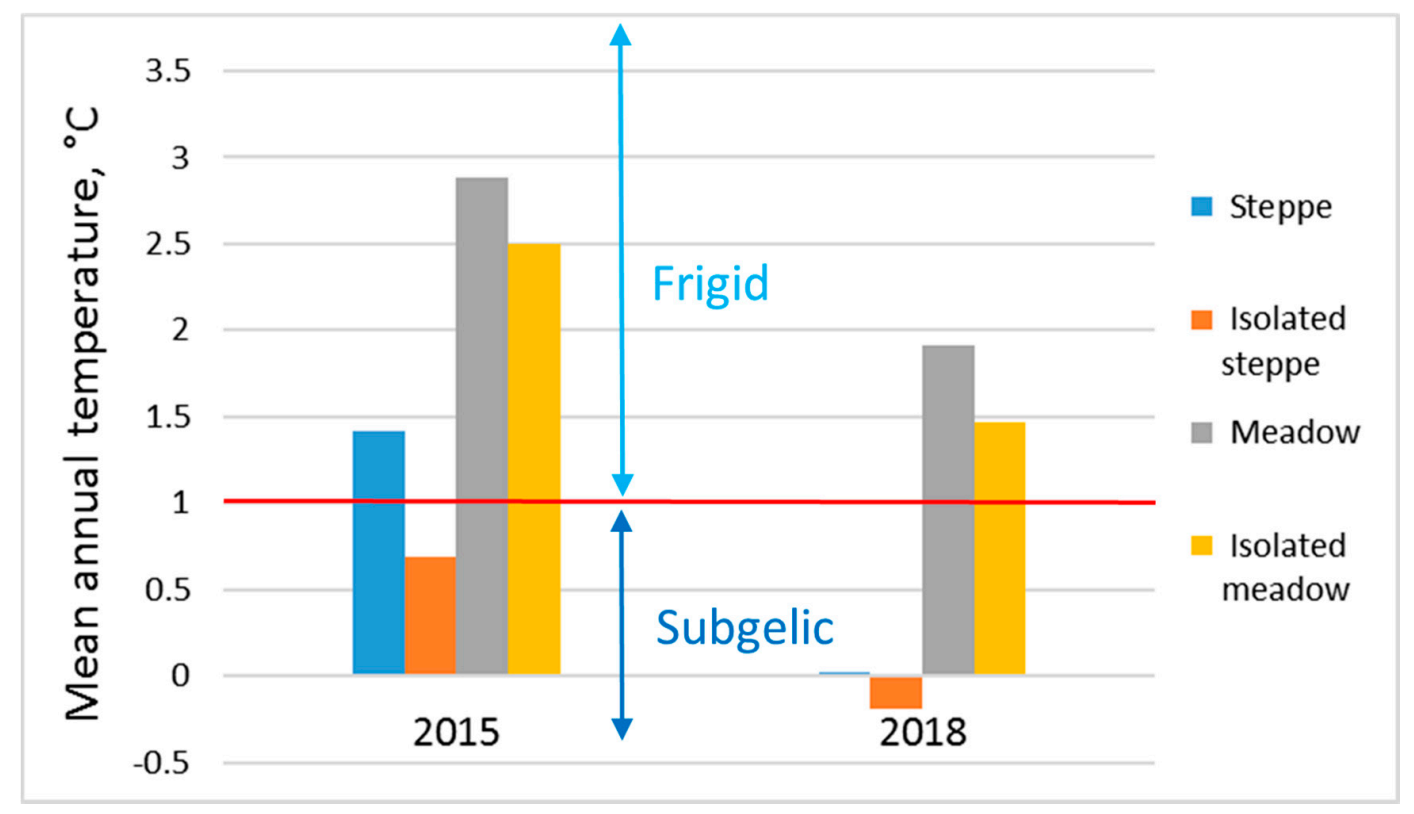

Figure 11. The change in the average annual temperature of alas soils at a depth of $0.2 \mathrm{~m}$. 


\section{Discussion}

The temperature regime of alas soils has been well studied in hayfield alases [22-24], which are usually isolated during the growing season and open for grazing only in autumn. Alas soils vary in their degree of moisture and develop in concentric zones around lakes [7-9,22,23]. The greatest heat supply is typically for drier steppe soils located on the upper zones of alases. Here, the maximum penetration depth of active temperatures and the maximum sum of active temperatures in the humus horizons are observed. The temperature regime of alas steppe soils is classified as a frozen, moderately cold subtype. The heat supply of soil decreases closer to the lake of the alas. The temperature regime of the alas meadow soil is classified as a permafrost cold subtype and is characterized by optimal moisture for meadow grasses. Alas swamp soils develop close to the lake, the thermal regime of which belongs to the very cold permafrost subtype $[7,25]$. Therefore, the heat supply of soils decreases as the soil is moistened in the hayfield of alas.

Our research demonstrates a slightly different picture of heat redistribution in pasture alas. Here, meadow soils located in the middle alas zone are the warmest. This indicates that the thermal isolation provided by vegetation cover has a more significant effect than the soil's thermophysical properties. It is known that thermal diffusivity in soils rises with increasing humidity and stabilizes in the area of moisture saturation. Therefore, in alases, steppe soils have the lowest thermal diffusivity, while meadow soils have the highest (Figure 8). The thermal diffusivity of the soil mainly determines the differentiation of the temperature regime, since the foliage projective cover of the grass in the pasture alas is approximately the same in all areas. As for hayfield alas, the observed reverse pattern of temperature redistribution is primarily associated with the obscuring role of vegetation cover. The sufficiently moistened meadow soils under well-developed plant communities with dense grass stands receive significantly less heat than steppe soils in the upper alas zones under vegetation with a low projective cover.

The modern taiga-alas landscapes of Central Yakutia were mainly formed during the Holocene climatic optimum (5-9 thousand years ago) as a result of the melting of the underground ice-thermokarst $([7,26,27]$ and others). Since the thermokarst processes stop when the underground ice reserves are completely thawed, the alas relief represents an intermediate stage in the transformation of the plain formed by ice complexes in landscapes with little presence of ice. Experts note that the modern development of thermokarst in Central Yakutia is of a staged character-i.e., it attenuates during dry periods and intensifies during wet periods ([28-32] and others). In Central Yakutia, relatively humid years alternate with a certain periodicity with extremely dry years. Their periodicity has 11-, 30-40-, and 90-year cycles [33]. According to some researchers [7], contemporary thermokarstic processes are significantly slowed down due to the aridity of climatic conditions in Central Yakutia that developed at the end of the 20th century, and the further development of thermokarst can only be caused by a sufficiently humid climate [34].

However, the mean air temperatures for the last 5-year (2015-2019) and 10-year (2010-2019) periods are noted as the highest in the entire history of observations, according to the World Meteorological Organization. In 2019, the global mean annual air temperature was $1.1^{\circ} \mathrm{C}$ higher than that of the pre-industrial period (1850-1900) [35].

In Yakutia, the mean annual air temperature has been growing over the past half-century. The maximum positive trends in the mean annual temperature $\left(>0.6^{\circ} \mathrm{C} / 10\right.$ years $)$ were observed in Central Yakutia and in the valleys of the middle course of the Indigirka and Kolyma rivers. The air temperature over a 50-year period increased by more than $3{ }^{\circ} \mathrm{C}$ in these relatively small areas [36]. The steadily increasing linear trend is observed by the weather station in Yakutsk [37]. Here, the mean annual air temperature rose from $-10.4{ }^{\circ} \mathrm{C}$ to $-7.5^{\circ} \mathrm{C}$ for the period from 1966 to 2014 .

The unstable character of precipitation is one of the main effects of climate change. The variability in precipitation has a multidirectional character in Yakutia. On its territory, the mean annual range of precipitation is characterized by an interval of trend changes from -8 to $16 \mathrm{~mm} / 10$ years. Most of the territory of the Republic (about $73 \%$ ) belongs to areas with positive trends, and about $27 \%$ belongs to 
areas with negative trends. In Northeast and Central Yakutia, trends of $4-8 \mathrm{~mm} / 10$ years dominate [36]. The change in the thermal regime of soils is affected not only by changes in air temperatures but also by the thickness of the snow cover [38,39]. Long-term observations in Central Yakutia show that the amplitude of fluctuations in the mean winter thickness of the snow cover has grown almost twice since 1997 [37]. An analysis of the long-term data from the Churapcha weather stations also shows significant fluctuations in the mean winter and maximum thickness snow cover in the Lena-Amga interfluve over the past 20 years (Figure 12).

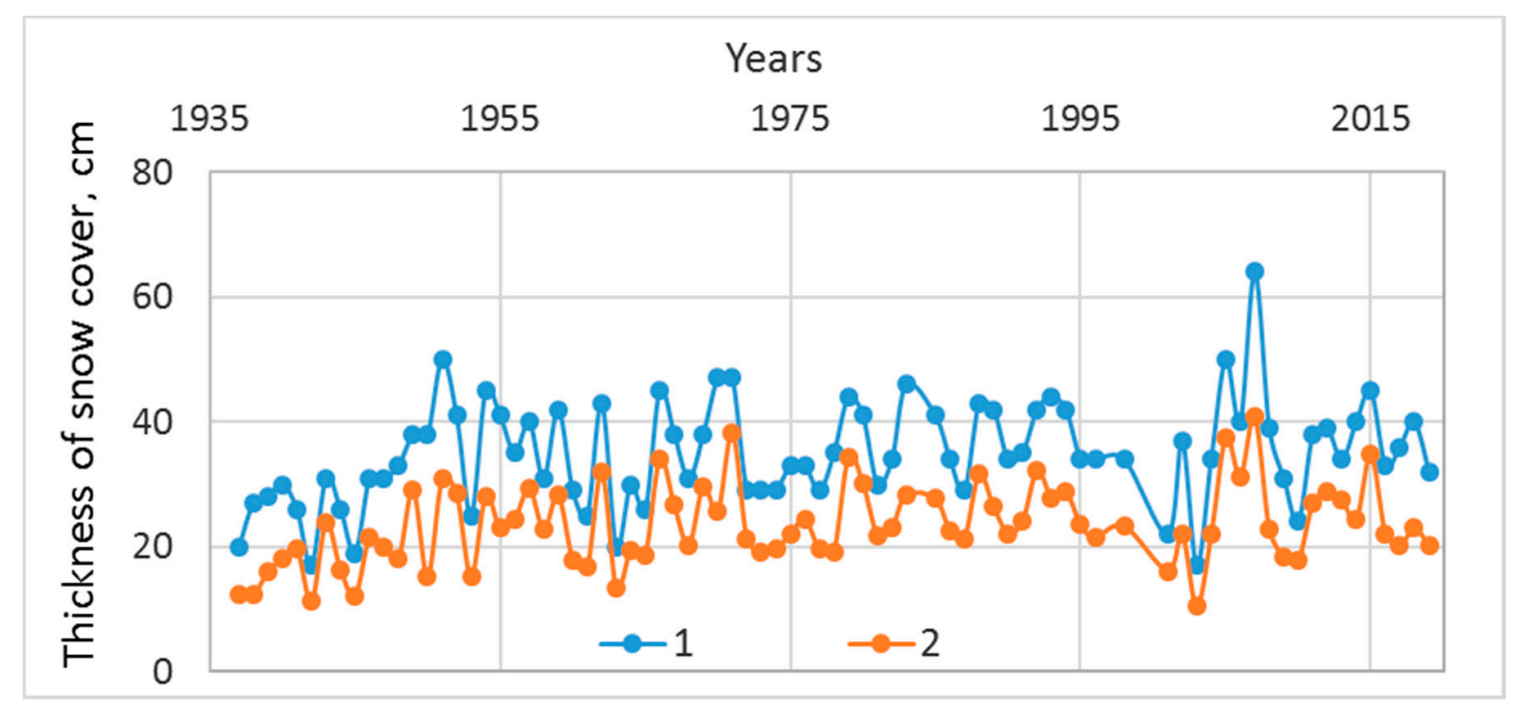

Figure 12. Dynamics of the maximum and mean depth of snow cover by surveys of snow cover (weather station Churapcha). 1-maximum thickness of the snow cover; 2-average thickness of the snow cover during the winter.

Contemporary climate change, including air temperature and snow cover thickness, undoubtedly affects the thermal regime of permafrost grounds in the natural landscapes of Central Yakutia and causes transformations in their structure and functioning [40]. Due to climatic factors, dramatic changes occur in the thermal regimes of the frozen soils. During the years with maximum snow thickness, the active layer weakly freezes, causing an increase in the depth of seasonal thawing in the following summer. The same assumptions were made in studies of the regions of Western Siberia, where the maximum thickness of snow cover increased by 40\% in 2001-2010 compared to 1966-2000 [41].

In addition to the above-mentioned climatic factors, the anthropogenic factor also has a significant effect on the increase in the depth of seasonal thawing, which requires more in-depth study in a cryolithozone context of Yakutia. Studies in non-permafrost regions of the planet show that grazing significantly affects the thermal properties and temperature conditions of the soil [12-14]. In some cases, with the increasing intensity of livestock grazing, the temperature of the soil increases exponentially. In this case, the soil heats up several times higher than from the effect of global warming alone [15]. In general, most authors [12-17] share the opinion that moderate grazing improves the thermal conditions of the soil, increases the duration of the growing season, accelerates the cycle of nutrients, and improves the quality of feed in non-permafrost regions.

As our long-term observations demonstrate, a similar situation is observed with grazing on alas soils. The mean annual temperature at a depth of $0.2 \mathrm{~m}$ increased by $0.4-1.7^{\circ} \mathrm{C}$, the sum of active temperatures increased by $390-650^{\circ} \mathrm{C}$, and the penetration depth of active temperatures increased by $0.2-0.3 \mathrm{~m}$ depending on the climatic parameters of the year and soil type. We believe that the increase in the heat supply of soils on pasture alas is associated not only with the destruction of vegetation during summer overgrazing but also with the absence of winter grazing on them. In winter, cattle in Yakutia are traditionally kept indoors, and Yakut horses prefer to forage during the winter in the 
meadows of the valleys of taiga grassy rivers and hayfields of alas, which are not subjected to summer grazing. Meanwhile, on alases, located near settlements and subject to constant summer overgrazing, there is no pasture feeding of horses in winter, and therefore the snow cover in such areas remains almost untouched.

If grazing in non-permafrost areas largely has favorable consequences, then in the zone of permafrost the warming of the soil can disrupt the established thermal regime and provoke the activation of thermokarst processes. Our research also suggests the activation of cryogenic processes in the context of a changing climate observed in the alas of the Lena-Amga interfluve. We identified a developing hummocky microrelief at the bottom of Niagaatta alas, where the height of the hummocks does not exceed $0.2 \mathrm{~m}$ and the diameter reaches $13 \mathrm{~m}$. These formations are most clearly visible in satellite imagery WorldWiew-2 in the zone of swamp and meadow soils (Figure 1). We assume that the depth of seasonal thawing has reached the upper boundary of the ice complex. As a result, the development or resumption of thermokarst processes has begun.

\section{Conclusions}

The average height of grass stands and their foliage projective cover increases significantly on alas soils isolated from grazing. However, the number of species gradually decreases. At the same time, there is a noticeable decrease in the proportion of synanthropic grasses.

Grazing significantly affects the temperature regime of alas soils. Changes in the structure of alas vegetation cover caused by the grazing of cattle affect the soil microclimate; the mean annual soil temperature increases at a depth of $0.2 \mathrm{~m}$ (almost always above $0{ }^{\circ} \mathrm{C}$ ), and the sum and penetration depth of active temperatures increases. The most severe changes in the temperature regime occur in years with an abnormally high snow cover. The observed warming of the soil undoubtedly has a favorable effect on soil organisms. However, in a warming climate heavy grazing can lead to a violation of the permafrost regime and thus provoke or strengthen thermokarst phenomena. Further research should aim to identify and select the most optimal level of grazing for the sustainable development of pasture alas in Central Yakutia.

Author Contributions: V.M. and G.S. conceived and designed the research; V.M., L.G., and A.G. collected and analyzed the data; and all the authors wrote the paper. All authors have read and agreed to the published version of the manuscript.

Funding: This research received no external funding.

Acknowledgments: Research was conducted within the project of the State task of the Ministry of Education and Science of the Russian Federation, FSRG-2020-0018 "Study of the functioning of the Arctic and Subarctic ecosystems of Yakutia in the conditions of increasing anthropogenic impact and global climate change".

Conflicts of Interest: The authors declare no conflict of interest.

\section{References}

1. Gogoleva, A. Yakuts Problems of Ethnogenesis and Culture Formation; Yakut State University Press: Yakutsk, Russia, 1993; p. 200.

2. Gogoleva, P.A. Classification and brief characteristic of the grass vegetation of the Alases of the Lena-Amginsky interfluve. In Ecol. Coenol. Mead. Centr. Yakutia; Yakut State University Press: Yakutsk, Russia, 1978; pp. 100-127.

3. Yakushev, D. Scientific Basis for Improving and Using Hayfields and Pastures in Yakutia; Yakut Book Press: Yakutsk, Russia, 1986; p. 174.

4. Gogoleva, P.; Kononov, K.; Mirkin, B.; Gogoleva, C. Syntaxonomy and Symphitosociology of Alas Vegetation of Central Yakutia; Irkutsk University Press: Irkutsk, Russia, 1987; p. 176.

5. Gavrilieva, L.D. The effect of grazing on the species composition of alas meadows. In Problems of Northern Agriculture: Selection, Forage Production, Ecology: Collection of Scientific Works, Yakutsk, Russia; Siberian Branch of the Russian Academy of Agricultural Sciences: Novosibirsk, Russia, 2000; pp. 141-151. 
6. Desyatkin, R.V. About some environmental problems of agricultural production in Yakutia. Ecol. Prob. Yakutia 1996, 1, 112-122.

7. Desyatkin, R. Soil Formation in Thermokarst Depressions-Alases of Cryolithozone; Science Press: Novosibirsk, Russia, 2008; p. 323.

8. Ivanov, A.; Mironova, S.; Savvinov, D. Alas Meadows of the Lena-Vilyuisky Interfluve of Central Yakutia under Various Modes of Use; Science Press: Novosibirsk, Russia, 2004; p. 112.

9. Savvinov, D.; Mironova, S.; Bosikov, N. Alas Ecosystems: Structure, Functioning, Dynamics; Science Press: Novosibirsk, Russia, 2005; p. 264.

10. Savvinov, G. Ecological and Soil Complexes of Yakutia; Nedra Business Center Publisher: Moscow, Russia, 2007; p. 312.

11. Danilov, P.P.; Savvinov, G.N.; Gotovtsev, C.P.; Makarov, V.C.; Alekseev, G.A. Features of Changes of the Alas Soils of Lena-Amginsky Interfluve; Questions of Geography of Yakutia: Yakutia, Russia, 2013; pp. 90-94.

12. Gan, L.; Peng, X.; Peth, S.; Horn, R. Effects of grazing intensity on soil thermal properties and heat flux under Leymus chinensis and Stipa grandis vegetation in Inner Mongolia, China. Soil Till. Res. 2012, 118, 147-158. [CrossRef]

13. Odriozola, I.; García-Baquero, G.; Laskurain, N.A.; Aldezabal, A. Livestock grazing modifies the effect of environmental factors on soil temperature and water content in a temperate grassland. Geoderma 2014, 235, 347-354. [CrossRef]

14. Vaieretti, M.V.; Iamamoto, S.; Harguindeguy, N.P.; Cingolani, A.M. Livestock grazing affects microclimate conditions for decomposition process through changes in vegetation structure in mountain grasslands. Acta Oecol. 2018, 91, 101-107. [CrossRef]

15. Yan, Y.; Yan, R.; Chen, J.; Xin, X.; Eldridge, D.J.; Shao, C.; Wang, X.; Lv, S.; Jin, D.; Chen, J.; et al. Grazing modulates soil temperature and moisture in a Eurasian steppe. Agric. For. Meteorol. 2018, 262, 157-165. [CrossRef]

16. Chai, J.; Yu, X.; Xu, C.; Xiao, H.; Zhang, J.; Yang, H.; Pan, T. Effects of yak and Tibetan sheep trampling on soil properties in the northeastern Qinghai-Tibetan Plateau. Appl. Soil Ecol. 2019, 144, 147-154. [CrossRef]

17. Zhan, T.; Zhang, Z.; Sun, J.; Liu, M.; Zhang, X.; Peng, F.; Tsunekawa, A.; Zhou, H.; Gou, X.; Fu, S. Meta-analysis demonstrating that moderate grazing can improve the soil quality across China's grassland ecosystems. Appl. Soil Ecol. 2020, 147. in press. [CrossRef]

18. Field Geobotany; Nauka: Moscow, Russia, 1964; 530p.

19. Mirkin, B.M. Theoretical Bases of a Modern Fitotsenologiya; Kolos: Moscow, Russia, 1985; 136p.

20. Braun-Blanquet, J. Pflanzensoziologie. Grundzuge der Vegetationskunde; Springer-Verlag: Wien, NY, USA, 1964; 865p.

21. Dimo, V.N. Thermal Regime of Soils in the USSR; Kolos: Moscow, Russia, 1972; 360p.

22. Dmitriev, A.I. Features of the hydrothermal regime and agrophysical properties of alas soils. In Climate. The Soil. Permafrost: Comprehensive Studies in Areas of Siberia and the Far East; Science. Sib. Department Press: Novosibirsk, Russia, 1991; pp. 49-54.

23. Dmitriev, A.I. Hydrothermal Regime of Alas Soils of the Lena-Amga Interfluve; Geographical Sciences: Ulan-Ude, Russia, 1997; 17p.

24. Makarov, V.S.; Savvinov, G.N. Potential of soil moisture in alas soils. Prob. Reg. Ecol. 2018, 5, 83-87.

25. Savvinov, G.N.; Pesterev, A.P.; Dmitriev, A.I. Hydrothermal resources of permafrost soils in Central Yakutia and the problems of their regulation. In Climate and Permafrost: Comprehensive Research in Yakutia; Publishing House of the Institute of Permafrost SD RAS: Yakutsk, Russia, 2000; pp. 104-110.

26. Kaplina, T.N.; Lozhkin, A.V. Age of alas deposits of the Primorsky lowland of Yakutia. Proc. USSR Acad. Sci. 1979, 2, 69-76.

27. The Structure and Absolute Geochronology of Alas Deposits of Central Yakutia; Publishing House Science: Novosibirsk, Russia, 1979; 95p.

28. Grave, N.A. Fossil ices of the watershed of Lena and Aldan. Proceedings of the Institute of permafrost them. V. A. Obrucheva 1944, 4, 10-32.

29. Soloviev, P.A. The Permafrost Zone of the Northern Part of the Lena-Amga Interfluve; USSR Academy of Sciences Publishing House: Moscow, Russia, 1959; 144p.

30. Soloviev, P.A. Alas Thermokarst Relief of Central Yakutia. In Proceedings of the Second International Conference on Permafrost, Yakutsk, Russia, 13-28 July 1973. 
31. Bosikov, N.P. Dynamics of levels and development of alas lakes in Central Yakutia. Proc. All-Union Geogr. Soc. 1977, 109, 357-361.

32. Bosikov, N.P. Evolution of the Alases of Central Yakutia; Publishing House of the Institute of Permafrost SB RAS: Yakutsk, Russia, 1991; 128p.

33. Gavrilova, M.K. The Climate of Central Yakutia; Yakutsk Prince Publishing House: Yakustk, Russia, 1973; 119p.

34. Sukhodrovsky, V.L. Exogenous Relief Formation in the Permafrost Zone; Publishing House Science: Mosvka, Russia, 1979; 280p.

35. WMO Statement on the State of the Global Climate in 2019. Available online: https://public.wmo.int/en/ourmandate/climate/wmo-statement-state-of-global-climate (accessed on 15 November 2019).

36. Gorokhov, A.I.; Fedorov, A.N. Current trends in climate change in Yakutia. Geogr. Nat. Resour. 2018, 2,111-119. [CrossRef]

37. Varlamov, S.P.; Skachkov, Y.U.B.; Scriabin, P.N. Modern Climate Changes and Thermal Regime of Soils in the Natural Landscapes of Central Yakutia. In Proceedings of the Materials of the Fifth Conference of Russian Geocryologists, Moscow, Russia, 14-17 June 2016; Volume 2, pp. 20-26.

38. Zhang, T.; Osterkamp, T.E.; Stamnes, K. Effects of climate on the active layer and permafrost on the North Slope of Alaska. USA Permafr. Periglac. Process. 1997, 8, 45-67. [CrossRef]

39. Frauenfeld, O.W.; Zhang, T.J.; Barry, R.G. Interdecadal changes in seasonal freeze and thaw depths in Russia. J. Geophys. Res. 2004, 109, D5. [CrossRef]

40. Iijima, Y.; Fedorov, A.N.; Park, H. Abrupt increases in soil temperatures following increased precipitation in a permafrost region, central Lena River basin, Russia. Permafr. Periglac. Process. 2010, 21, 30-41. [CrossRef]

41. Osokin, N.I.; Sosnovsky, A.V. Spatial and temporal variability of the thickness and density of snow cover in Russia. Ice Snow 2014, 54, 72-80.

(C) 2020 by the authors. Licensee MDPI, Basel, Switzerland. This article is an open access article distributed under the terms and conditions of the Creative Commons Attribution (CC BY) license (http://creativecommons.org/licenses/by/4.0/). 